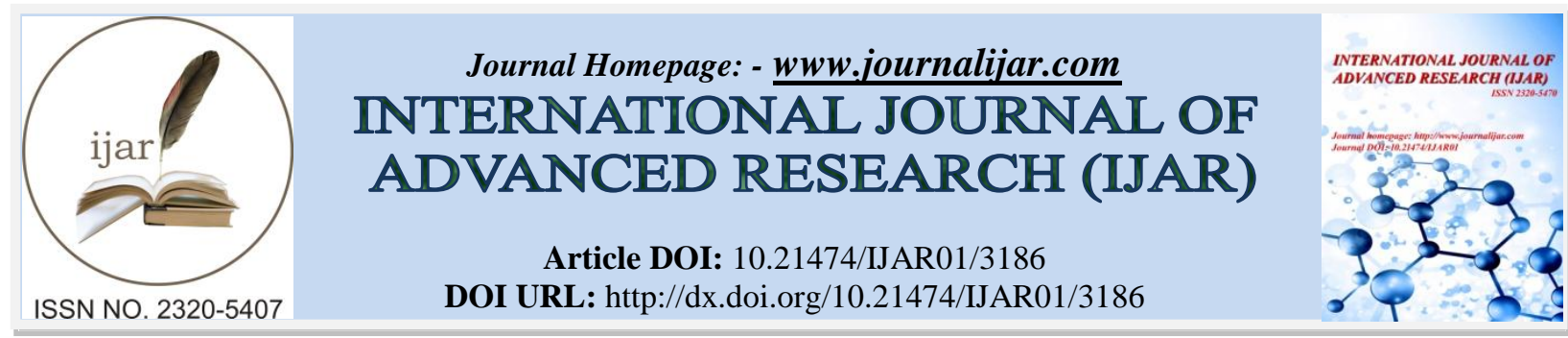

RESEARCH ARTICLE

\title{
THE EFFECT OF ALKALOIDS, SAPONINSAND THYMOQUINONE OF NIGELLA SATIVA SEEDS ON BIOFILM PRODUCTION, MOTILITY, OUTER MEMBRANE PROTEINS AND LIPOPOLYSACCHARIDE OF SOME BACTERIA.
}

\author{
Mohamed Shohayeb ${ }^{1}$ and Eman Halawani ${ }^{2}$. \\ 1. Taif University, Faculty of pharmacy, Department of microbiology, Taif, Saudi Arabia. \\ 2. Taif University, Faculty of Science, Department of Biology, Taif, Saudi Arabia.
}

\section{Manuscript Info \\ Manuscript History}

Received: 02 December 2016

Final Accepted: 12 January 2017

Published: February 2017

\section{Key words:-}

Nigella sativa, bacteria, thymoquinone, alkaloids ,saponins, antimicrobial,anticancer.

\begin{abstract}
Alkaloids, saponinsand thymoquinone ofNigella sativaare active against both Gram-positive and Gram-negative bacteria. Subinhibitory concentrations of theseconstituentswere tested for their effect on biofilm production, motility and the expression of the proteins and the lipopolysaccharides of the outer membrane of Gram-negative bacteria. While all the three tested constituents reduced the biofilm formation byE. coli, only saponins and alkaloids reducedthe biofilm formation inK. pneumoniae and Sal. Typhimurium. Nonetheless, alkaloids, saponinsand thymoquinone, enhanced the biofilm formation in $P$. aeruginosa and Sh. flexneri. On the other hand,thymoquinone inhibited the motility of Escherichia coli, P. aeruginosa and Sal. Typhimurium. There were changes in the level of expression of seven and three outer membrane proteins of $E$. coli and $P$. aeruginosa, respectively. Amongst these changes in $E$. coli, the amounts of OmpF apparently decreased and those ofOmpA increased. Also, three outer membrane proteins of $P$. aeruginosa were affected by the phytochemicals includingOprF. The expression of the latter was increased by alkaloids. Electron microscopy revealed some morphological changes inS. aureus and $P$. aeruginosa. It may be concluded that thymoquinone, alkaloids and saponins affect several pathogenesis mechanisms in both Gram-positive and Gram-negative bacteria.
\end{abstract}

Copy Right, IJAR, 2017,. All rights reserved.

\section{Introduction:-}

For centuries, Nigella sativa L. (Family Ranunculaceae) seeds have been traditionally used in bakery as pungent appetizer and aromatic, and folk medicine in the Middle East, Eastern Europe, Asia, and Africa, as thermogenic, diuretic, expectorant, purgative, stimulant, sudoriferous, sedative, carminative and for many other diseases in different $(1,2)$. Muslim communities, in particular, considered $N$. sativaseeds as one of the most important prophetic medicinal plants because its healing effects were referred to by the Prophet Muhammad (Peace be upon him) (3).

Nigella sativa seeds contain different pharmacologically active constituents like alkaloids, saponins and essential oil (4). These constituents have been investigated for their pharmacological effects both in vitroand in vivo $(5,6)$. Theyhave been demonstrated to enhance the immune system (7), and to have galactagogue, carminative, laxative

Corresponding Author:- Mohamed Shohayeb.

Address:- Taif University, Faculty of pharmacy, Department of microbiology, Taif, Saudi 
(2), anti-inflammatory (8), anti-cancer $(9,10)$ antimicrobial (11-15), anti-parasitic (16), antioxidant (17), hypoglycemic (18) activities.

The different extracts of $N$. sativa seeds were found to possess broad-spectrum antimicrobial activity against bacteria, viruses and fungi (19). This broad-spectrum of antimicrobial activity may be attributed to their effect on the key biochemical elements of microorgansims (20).

Extracts of $N$. sativa were found to inhibit both Gram-positive and Gram-negative bacteria. Water extracts of the seeds were active against Staphylococcus aureus $(21,22)$. Diethyl-ether,Methanol and chloroform extracts of the seed of N. sativa inhibited the growth of Escherichia coli, Helicobacter pylori,Bacillus subtilis and Streptococcus fecalis $(23,24)$.

The antibacterial activity of crude extracts and phytochemicals of $N$. sativa have also been found to be active against multi-drug-resistant bacteria, including both Gram-positive bacteria like Staphylococcus aureus and Gram-negative bacteria like Pseudomonas aeruginosa and Escherichia coli $(15,25,26)$.

Some purified constituents of $N$. sativa have also been tested for their antibacterial activity. The first reported constituent which possessed an anti-bacterial activity was the phenolic fraction of $N$. sativa oil (13). The essential oil of $N$. sativa and some of its components like thymoquinone and hydrothymoquinonefvwere found to be lethal to fungi, Gram-positive and Gram-negative bacteria (27-31). The antibacterial activity of alkaloids and saponins, of $N$. sativa, were evaluated both qualitatively and quantitatively $(15,32,33)$.

In a previous study, we demonstrated the antibacterial activity of alkaloids, saponins and thymoquinone of $N$. sativa seeds on a wide range of antibiotic sensitive and resistant bacteria (15).In this report, we investigated the effect of these active constituents on slime production, motility, outer membrane proteins and lipopolysaccharide.

\section{Materials and Methods:-}

\section{Bacteria and chemicals:-}

The six pathogenic bacteria used were Escherichia coli ATCC 35218, Salmonella enterica serovarTyphimurium ATCC 14028 (Sal.Typhimurium, Pseudomonas aeruginosa ATCC 27853 (P. aeruginosa),Klebsiella pneumonia (K. pneumoniae), Shigellaflexneri(Sh. Flexneri) and Staphylococcus aureus (S. aureus) were clinical isolates of the culture collection of the Department of Microbiology, College of Pharmacy, Taif University. Thymoquinone and organic solvents were purchased from Sigma-Aldrich.

\section{Extraction of alkaloids:-}

Powdered seeds of the plant were extracted with $70 \%$ methanol. The extract was evaporated under reduced pressure, dissolved into distilled water and acidified with $3 \%$ hydrochloric acid. The solution was extracted with petroleum ether. The acidic solution was made alkaline with $25 \%$ ammonium hydroxide $(\mathrm{pH} 9-10)$ and then extracted with chloroform. The combined chloroform extracts were dried to get the crude $N$. sativa alkaloids (34).

\section{Extraction of saponins:-}

Powdered seeds of the plant were defatted with n-hexane. Further extraction was performed with $70 \%$ methanol. After evaporation of the methanol under vacuum, the crude residue was acidified with 5\% hydrochloric acid and left overnight in the refrigerator. The precipitate was extracted with chloroform: methanol (75:25), to get crude saponins (35).

\section{Biofilm production (36):-}

Thymoquinone, saponinsand alkaloids of $N$. sativa were two-fold serially diluted with a minimum medium (M9) to give series of concentrations in sterile 96-well polystyrene microtitration plates. Each series of dilutions was inoculated with $10^{4} \mathrm{CFU} / \mathrm{ml}$ of the tested bacteria and incubated at $37^{\circ} \mathrm{C}$ for 18 hours. Bacteria suspension was aspirated and wells were washed-buffer saline ( $\mathrm{pH} 7.5$ ), ethanol, and stained with $0.1 \%$ crystal violet for $30 \mathrm{~min}$. Wells were rinsed with water and filled with ethanol for $30 \mathrm{~min}$ and their contents were transferred to another microtiter plate. Plates were read at $595 \mathrm{~nm}$ using an ELISA reader. 
Effect of some constituents on swarming and motility of bacteria (37):-

Bacteria were grown onto swarming or swarming plates containing subinhibitory concentrations of $N$. sativa: Plates were incubated overnight at $30^{\circ} \mathrm{C}$ and zones of swimming or swarming were measured and compared to those of control plates.

\section{Effect on outer-membrane proteins(38):-}

Log phase bacteria treated with sub-inhibitory concentrations of some constituents of $N$. sativa were harvested and sonicated. Debris was harvested by centrifugation and membranes were collected by high-speed centrifugation. Inner and outer membranes were separated by differential solubilisation and with sarkosyl and subjected to SDSPAGE

\section{Purification of lipopolysaccharide:-}

Log phase bacterialcells were lysed at $100^{\circ} \mathrm{C}$ with SDS in presence of glycerol and $\beta$-mercaptoethanol. Lysed cells were treated with proteinase $\mathrm{K}$ at $60^{\circ} \mathrm{C}$ for $1 \mathrm{hr}(\mathbf{3 9})$, subjected to SDS-PAGE (40).

\section{SDS-PAGE:-}

Components of different fractions were separated by the SDS-PAGE as described before. Briefly, proteins were stacked in $4.5 \%$ acrylamide and separated in $12.5 \%$ acrylamide. Gels were run at a constant current of $20 \mathrm{~mA}$ per gel, and proteins were visualised with Coomassie blue (40) or silver stain $(39,41)$.

\section{Electron microscopy:-}

Bacterial cells grown at a sub-lethal concentration of the purified constituents were fixed with $2.5 \%$ glutaraldehyde and were negatively stained with $2 \%$ (w/v) phosphotungstic acid in $0.1 \mathrm{M}$ sodium phosphate buffer (pH 6.5)(42). Bacteria were examined by transmission electron microscope (JEM, Japan).

\section{Statistical Analysis:-}

All determinations were carried out in triplicates and the statistical analyses were carried out using SPSS 13.0 and Microsoft Excel programs

\section{Results:-}

Biofilm formation by S. aureus, P. aeruginosa, E. coli, K. pneumoniae, Sh. flexneri and Sal. Typhimurium, was investigated in presence and absence of the thymoquinone, saponins and alkaloids (Table 1). Biofilm production by $S$. aureus was not very much affected by the three active constituents of $N$. sativa. On the other hand, while biofilm production by E. coli, was reduced, its production by $P$. aeruginosa and Sh. flexneri was enhanced (Table 1). The percentage of production of biofilm by E. coli was 19-85\% compared to the control. On the other hand, biofilm production was $210-235 \%$ and $117-240 \%$ increased as compared with the control in the case of $P$. aeruginosa and Sh. flexneri respectively (Table 1). In the cases of K. pneumoniae and Sal. Typhimurium there was an enhancement of biofilm production by thymoquinone and a reduction of production by both alkaloids and saponins at $1 / 2$ MIC (Table 5).

Table 1:- Effect of some active contents of $N$. sativa on biofilm production by different types of bacteria (in M9 medium)

\begin{tabular}{|c|c|c|c|c|c|c|c|}
\hline \multirow[t]{2}{*}{ Constituent } & \multirow[t]{2}{*}{ Conc. } & \multicolumn{6}{|c|}{ Bacteria } \\
\hline & & $\begin{array}{l}\text { Staph. } \\
\text { aureus }\end{array}$ & $\begin{array}{l}\text { Pseudomonas } \\
\text { aeruginosa }\end{array}$ & $\begin{array}{l}\text { Escherichia } \\
\text { coli }\end{array}$ & $\begin{array}{l}\text { Klebsiella } \\
\text { pneumoniae }\end{array}$ & $\begin{array}{l}\text { Shigellafl } \\
\text { exneri }\end{array}$ & $\begin{array}{l}\text { Salmonella } \\
\text { Typhimurium }\end{array}$ \\
\hline & & \multicolumn{6}{|c|}{$\%$ biofilm production compared to control } \\
\hline \multirow[t]{2}{*}{ Thymoquinone } & $1 / 2 \mathrm{MIC}$ & 101.6 & 125.3 & 29.9 & 125.3 & 235.0 & 153.4 \\
\hline & $1 / 4 \mathrm{MIC}$ & 103.7 & 112.7 & 85.1 & 154.1 & 240.0 & 88.6 \\
\hline \multirow{2}{*}{ Saponins } & $1 / 2 \mathrm{MIC}$ & 106.5 & 140.6 & 19.4 & 30.3 & 125.4 & 50.6 \\
\hline & $1 / 4 \mathrm{MIC}$ & 95.0 & 110.2 & 26.9 & 25.0 & 143.4 & 53.2 \\
\hline \multirow{2}{*}{ Alkaloids } & $1 / 2 \mathrm{MIC}$ & 107.1 & 210.7 & 30.9 & 54.5 & 1260 & 653 \\
\hline & $1 / 4 \mathrm{MIC}$ & 104.6 & 125.3 & 39.4 & 102.6 & 117.7 & 74.7 \\
\hline
\end{tabular}


The effect of thymoquinone and saponins on swimming capacity of three motile bacteria (P. aeruginosa, E. coli, and Sal. Typhimurium) was investigated (Table 1). While thymoquinone inhibited the motility of the tested bacteria, saponins enhanced it (Table 2). The diameters of zone of swarming of untreated bacteria, were 11,8 , and $20 \mathrm{~mm}$ for Ps. aeruginosa, E. coli and Sal. Typhimuriumrespectively, while their respective swarming diameters in presence of $1 / 2$ the MICs of saponins were 22, 20 and 50mm (Table 2).

Table 2:- Effect of phytochemicals on swimming of bacteria

\begin{tabular}{|c|c|c|c|c|}
\hline \multirow[t]{2}{*}{ Constituent } & \multirow[t]{2}{*}{ Conc. } & \multicolumn{3}{|l|}{ Bacteria } \\
\hline & & Ps. aeruginosa & E. coli & Sal. Typhimurium \\
\hline & \multicolumn{4}{|c|}{ Zone Diameter $(\mathrm{mm})$} \\
\hline Control & 0 & 11 & 8 & 20 \\
\hline Thymoquinone & $\left.{ }^{(1 / 2} \mathrm{MIC}\right)$ & No $\mathbf{S}$ & No $S$ & No $\mathbf{S}$ \\
\hline & $\left({ }^{1 / 4} \mathrm{MIC}\right)$ & 13 & No $\mathbf{S}$ & No $\mathbf{S}$ \\
\hline Saponins & $\left.{ }^{(1 / 2} \mathrm{MIC}\right)$ & 22 & 20 & 50 \\
\hline & $\left({ }^{1 / 4} \mathrm{MIC}\right)$ & 18 & 13 & 44 \\
\hline
\end{tabular}

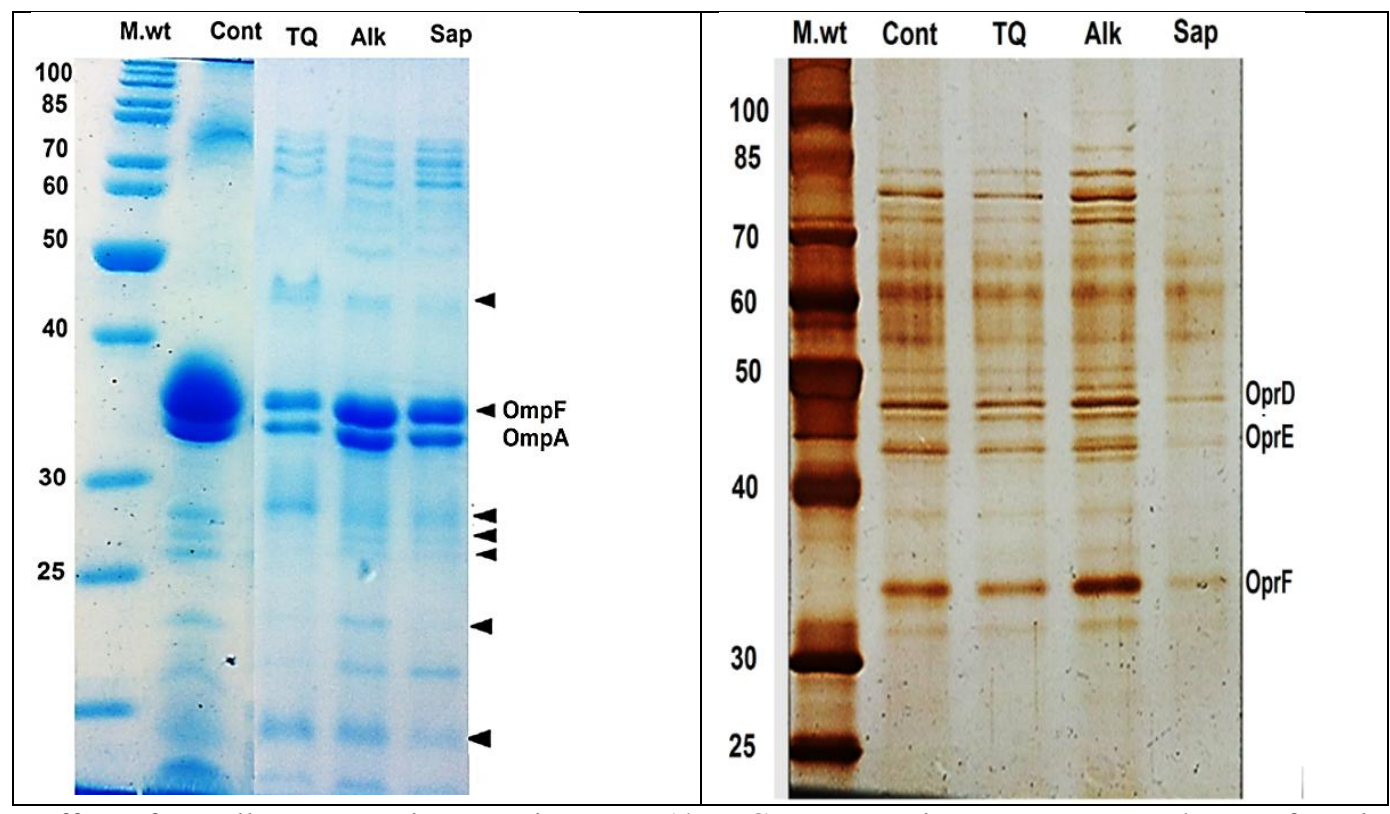

Fig 3:- Effect of Nigella sativa active constituents at $1 / 2 \mathrm{MIC}$ concentrations on outer membrane of Escherichia coli(left, Coomassie blue stained) and Pseudomonas aeruginosa (right, silver stained). Mw, molecular weight markers; TQ, thymoquinone; Alk, alkaloids; Sap, saponins.

Table 3:- Summary of the effect of Nigella sativa active constituents at $1 / 2 \mathrm{MIC}$ concentrations on the expression of outer membrane proteins of Escherichia coli and Pseudomonas aeruginosa

\begin{tabular}{|c|c|c|c|c|}
\hline \multirow[t]{2}{*}{ Bacteria } & \multirow{2}{*}{$\begin{array}{l}\text { Protein apparent molecular } \\
\text { wright }(\mathrm{kDa})\end{array}$} & \multicolumn{3}{|c|}{ Effect of Nigella sativa active constituent on protein level * } \\
\hline & & Thymoquinone & Alkaloids & Saponins \\
\hline \multirow{7}{*}{$\begin{array}{l}\text { Escherichia } \\
\text { coli }\end{array}$} & $36(\mathrm{OmpF})$ & - & - & - \\
\hline & 46 & + & + & + \\
\hline & $28(\mathrm{OmpA})$ & + & + & + \\
\hline & 27 & - & + & + \\
\hline & 26 & - & + & + \\
\hline & 22 & $\mathrm{NC}$ & $\mathrm{NC}$ & - \\
\hline & 17.5 & + & $\mathrm{NC}$ & $\mathrm{NC}$ \\
\hline \multirow{3}{*}{$\begin{array}{l}\text { Pseudomonas } \\
\text { aeruginosa }\end{array}$} & 86 & $\mathrm{NC}$ & + & $\mathrm{NC}$ \\
\hline & 80 & - & $\mathrm{NC}$ & - \\
\hline & 33 (OprF) & $\mathrm{NC}$ & + & $\mathrm{NC}$ \\
\hline
\end{tabular}


The changes of the apparent level of expression of some outer membrane proteins of E. coli and $P$. aeruginosa exposed to $1 / 2$ MICs are shown in figure 3 and table 3 . Changes in the levels of expression of seven proteins in $E$. coli and three proteins in P. aeruginosa were observed and

Thymoquinone caused an increase in the expression of 3 proteins in E. coli and a decrease in 3 others. On the other hand, it caused an apparent decrease in the amount of a protein which has a molecular weight of $80 \mathrm{kDa}$ in $P$. aeruginosa (Table 3). Alkaloids cause an increase in the level of 4 proteins and a reduction in one protein in $E$. coli and an increase in the level of expression of two proteinsone of which was OprFin P. aeruginosa (Table 3). Saponins increased the level of expression of 4 proteins and reduced two in $E$. coli and reduced the level of only one protein in P. aeruginosa(Table 3).

Thymoquinone, alkaloids and saponins affected the expression of lipopolysaccharides in $E$. coliand not $P$. aeruginosa. As shown in figure4, there was a decrease in the amount of high molecular weight LPS in E. coli treated with thymoquinone, alkaloids and saponins.

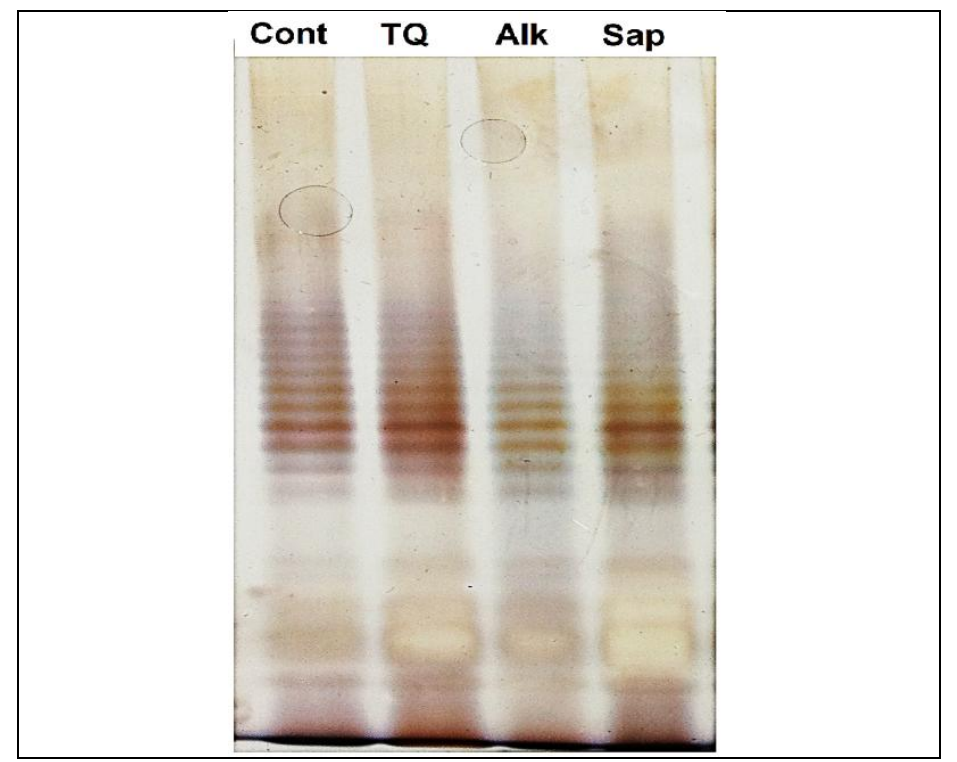

Fig 4: -Effect of Nigella sativa active constituents at 1/2 MIC concentrations on lipopolysaccharide of Escherichia coli. Mw, molecular weight markers; TQ, thymoquinone; Alk, alkaloids; Sap, saponins.

S. aureus, E. coli and P. aeruginosa as treated with thymoquinone, saponins and alkaloids, were examined for changes in their morphology. While no apparent changes in the morphology of E. coli, (data not shown), some changes were observed in both $P$. aeruginosa and $S$. aureus. Thymoquinone and alkaloids caused $P$. aeruginosa cells to become more elongated and thinner compared to the control (Fig. 1). This was more apparent in the case of thymoquinone. On the other hand, S. aureus exposed to saponins at sub-inhibitory concentration suffered from protoplasting and some cells suffered from the retraction of their cytoplasmic contents away from the cell wall as shown in Fig 5B.

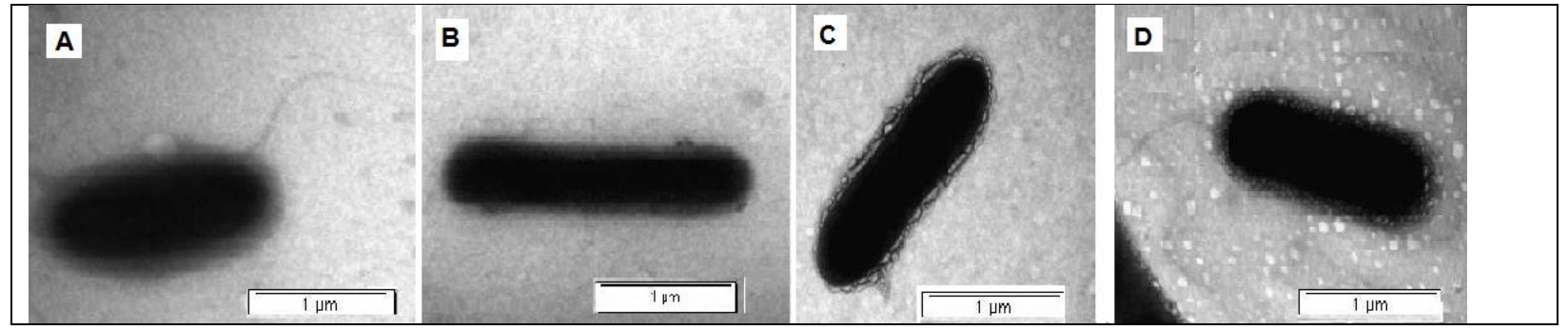

Fig. 1:- Pseudomonas aeruginosa after growth for $24 \mathrm{~h}$ in M9 (A) and in M9 containing subinhibitory concentration of thymoquinone (B), alkaloids (C), and saponins (D). 

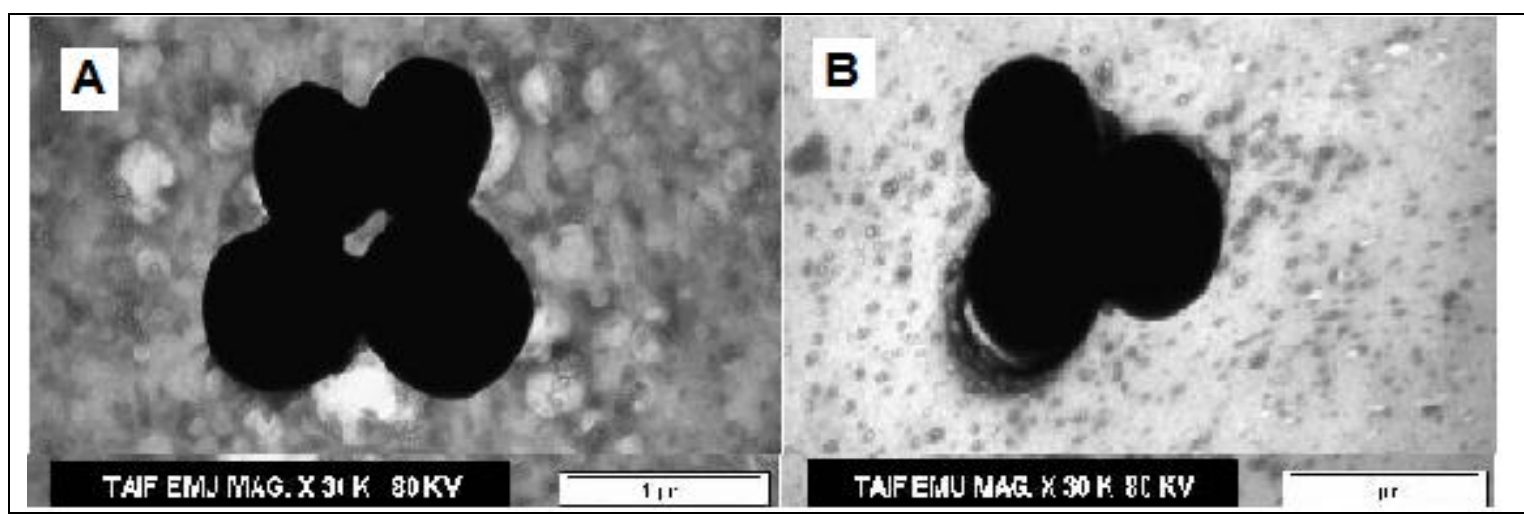

Fig. 2:- Staphylococcus aureus after growth for $24 \mathrm{~h}$ in M9 (A) and in M9 containing saponins at subinhibitory concentration (B).

\section{Discussion:-}

The saponins, alkaloids, and thymoquinone were previously reported to be inhibitory to different types of bacteria even though they might be multi-drug resistant clinical isolates $(15,32)$.In this study, we investigated the effect of subinhibitory concentrations of saponins, alkaloids, and thymoquinone of $N$. sativa on some pathogenesis mechanisms of some Gram-positive and Gram-negative.

Is this study, S. aureus, P. aeruginosa, E. coli, K. pneumonia, Sh. flexneri and Sal. Typhimurium, were grown at $1 / 2$ and $1 / 4$ the MICs of thymoquinone, saponins and alkaloids and were tested for their capability of forming biofilms.

Biofilms are formed on surfaces of living tissues, medical devices and contact lenses, etc. (43). Biofilms help bacteria to survive and withstand hostile conditions on surfaces and contribute to the persistence of chronic infections (44). Several studies have been performed to find natural antimicrobial agents that influence microbial biofilm formation (45-48).

While there was a reduction in the ability of $E$. coli to produce biofilms by the three tested constituents, only saponins and alkaloids were capable of reducing biofilm formation by K. pneumoniae and Sal. Typhimurium. On the other hand, biofilm formation was enhanced in P. aeruginosa and Sh. flexneri and was indifferent in the case of $S$. aureus.

The induction of biofilm formation, in P. aeruginosa, and the failure to reduce biofilm formation in $S$. aureus, contradicts with Chaieb, et al., (49), who reported a reduction in biofilm formation by both $S$. aureus and $P$. aeruginosa treated with thymoquinone. However, it should be mentioned that the inhibition detected was at concentrations higher than their reported MICs. Therefore, while thymoquinone caused inhibition of biofilm formation at concentrations 22 and $>512$, for $S$. aureus and $P$. aeruginosa respectively, the MICs reported were 8 and $>512$ respectively (49).

Motility plays a key role in the colonisation of surfaces by bacteria $(50,51)$. In this study, thymoquinone inhibited the motility and swarming of Escherichia coli, P. aeruginosa and Sal. Typhimurium. In a previous study,tannins of cranberry fruit and the hydrolysable tannin in pomegranate were reported to inhibit swarming motility but did not block swimming or twitching motilities (51). Sub-inhibitory concentrations of alkaloids like piperine of black pepper and reserpine of snakeroot, decreased bacterial swarming and swimming motilities (52). Tannic acid and epigallocathecingallate were found to block swarming motility in Pseudomonas aeruginosa (53).

Motility plays a key role in the colonisation of surfaces by bacteria $(51,54$. In this study, thymoquinone inhibited the motility and swarming of Escherichia coli, P. aeruginosa and Sal. Typhimurium. In a previous study,tannins of cranberry fruit and the hydrolysable tannin in pomegranate were reported to inhibit swarming motility but did not block swimming or twitching motilities (51).

Escherichia coli, P. aeruginosa and S. aureus treated with a sub-inhibitory concentration of thymoquinone, alkaloids and saponins were examined under transmission electron microscope for morphological changes. Thymoquinone and alkaloids caused cells of $P$. aeruginosa to become thinner and elongated, compared to the 
control. Though, the morphological changes might be attributed, to their effect on penicillin-binding proteins, however, this is not necessary because quinolone antibiotics, which do not bind to penicillin-binding proteins, affect the morphology of E. coli (55).

S. aureus exposed to saponins at a sub-inhibitory concentration suffered from protoplasting and retraction of the cytoplasmic contents away from the cell wall. Morphological changes of $S$. aureus exposed to aqueous extracts of green tea (56) or extracted catechingallates (57) have been reported in $S$. aureus. Methanolic extract of a soft sponge, Haliclona sp., caused internal shrinkage of methicillin-resistant S. aureus and B. subtiliscells which finally collapsed after prolonged exposure to the extract (58).

There is evidence that several outer membrane proteins are involved in adherence of bacteria to mammalian cells (59-61). In this study, the effect of thymoquinone, alkaloids and saponins at 1/2 MICs on the outer membrane proteins was examined. There were indeed apparent changes in the levels of expression of seven and three proteins in $E$. coli and $P$. aeruginosa respectively. While in $E$. coliOmpF outer membrane protein apparently decreased in amounts by treatment with the three constituents, OmpA increased.

On the other hand, three outer membrane proteins of $P$. aeruginosa were affected by the tested phytochemicals one of which was OprF. The expression of the latter was increased by the treatment with alkaloids. Recent studies have shown that the expression of $5 \%$ of bacterial promoters may be affected by sub-inhibitory concentrations of antibiotics (62). Likewise, it seems that phytochemicals like thymoquinone, alkaloids and saponins affect the expression of bacterial promoters.

The effect of phytochemicals on the expression of some bacterial proteins has been previously documented.Bioactive fraction 9EA-FC-B ofAcalyphawilkesianainhibited the production of MRSA by reducing the amount PBP2a in the matrix(63). Proteomic analysis of bacterial expression profiles following exposure to flower extracts of Melastomacandidum affected the expression of four proteins in E. coli and one protein in S. aureus (64).

In this study, alkaloids and saponins were found to reduce the amounts of high molecular weight Lipopolysaccharide (LPS) in E. coli.LPS is a main outer membrane component of Gram-negative bacteria (65).It causes pathophysiological effects such as fever, leucopenia, leucocytosis and Shwartzman reactivity (65). It is also involved in the attachment to host cells and it is important for the virulence and pathogenesis of many bacterial species, including Pseudomonas aeruginosa, Salmonella species, and Escherichia coli(66-68).

LPS is associated closely with the OmpF protein of the outermembrane (69). The low expression of OmpF caused by alkaloids and saponins might have a role in the decreased in the detected amounts of high molecular weight LPS. LPS are essential for the pathogenesis of bacteria. It is an important mechanism to evade complement activation (70). Thisimplies that alkaloids and saponins could affect the pathogenesis of E. coli.

\section{Conclusion:-}

Thymoquinone, saponins and alkaloids of $N$. sativaat subinhibitory concentrationsaffect motility, biofilm formation and the expression of some proteins and LPS of theouter membrane of bacteria. This presumably would affectthe pathogenesis of bacteria.

\section{References:-}

1. Sayed MD. Traditional medicine in health care, J. Ethnopharmacol. 1980;2:19-22.

2. Randhawa MA, Alenazi SA (2016) Neuropsychiatric Effects of Nigella sativa (Black Seed) - A Review. AlternIntegr Med 5: 209.

3. Hajra, N. (2011). Nigella sativa: the miraculous herb. Pakistan Journal of Biochemistry \& Molecular Biology, 44(1), 44-48.

4. Nickavar B, Mojab F, Javidnia K, Amoli MA. Chemical composition of the fixed and volatile oils of Nigella sativa L. from Iran. Z Naturforsch C. 2003;58(9-10):629-631

5. Ali BH and Blunden G (2003). Pharmacological and toxicological properties of Nigella sativa. Phytother. Res., 17: 299-304.

6. Assi, M. A., Noor, M. H. M., Bachek, N. F., Ahmad, H., Haron, A. W., Yusoff, M. S. M., \&Rajion, M. A. The Various Effects of Nigella Sativa on Multiple Body Systems in Human and Animals. PJSRR (2016) 2(3): 1-19. 
7. Salem ML, Alenzi FQ, Attia WY. Thymoquinone, the active ingredient of Nigella sativa seeds, enhances survival and activity of antigen-specific CD8-positive T cells in vitro. Br J Biomed Sci. 2011;68(3):131-137

8. Pichette A, Marzouk B, Legault J. Antioxidant, anti-inflammatory, anticancer and antibacterial ctivities of extracts from nigella sativa (black cumin) plant parts. J Food Biochem. 2012;36(5):539-546

9. Padhye S, Banerjee S, Ahmad A, Mohammad R, Sarkar FH. From here to eternity-the secret of Pharaohs: Therapeutic potential of black cumin seeds and beyond. Cancer Ther. 2008;6:495-510

10. Kumara SSM and Huat BT (2001). Extraction, isolation and characterization of anti-tumor principle, alphahedrin, from the seeds of Nigella sativa. Planta Med., 67: 29-32.

11. EmanHalawani (2009). Antibacterial Activity of Thymoquinone and Thymohydroquinone of

12. Nigella sativa L. and Their Interaction with Some Antibiotics. Adva in Biol Res 3 (5-6): 148-152,

13. Bakathir HA, Abbas NA. Detection of the antibacterial effect of Nigella sativa ground seeds with water. Afr J TraditComplAltern Med. 2011;8(2):159-164.

14. Suthar MP Patel PN Shah TG, Patel RK (2010). In vitro Screening of Nigella sativa Seeds for antifungal activity. International J. Pharmaceutical Appl. Sci., 1:84-91.

15. Haloci E, Manfredini S, Toska V, Vertuani S, Ziosi P, Topi I, Kolani H (2012). Antibacterial and antifungal activity assessment of Nigella Sativa essential oils. World Academy Sci., Engin.Technol., 66: 1198-1200.

16. Shohayeb, M., \&Halawani, E. (2012). Comparative antimicrobial activity of some active constituents of N. sativa L. World ApplSci J, 20, 182-189.

17. Mohamed AM, Metwally NM, Mahmoud SS. Nigella sativa seeds against Schistosomamansoni different stages. MemInstOswaldo Cruz. 2005;100(2):205-211.

18. Burits, M., \&Bucar, F. (2000). Antioxidant activity of Nigella sativa essential oil. Phytotherapy Research, 14(5), 323-328.

19. Mathur ML, Gaur J, Sharma R, Haldiya KR. Antidiabetic properties spice plant Nigella sativa. Journal of Endocrinology and Metabolism 2011;1:1-8

20. Forouzanfar, F., Bazzaz, B. S. F., \&Hosseinzadeh, H. (2014). Black cumin (Nigella sativa) and its constituent (thymoquinone): A review on antimicrobial effects. Iranian journal of basic medical sciences, 17(12), 929.

21. Monika T, Sasikala P, VijayaBhaskara Reddy M. A investigational of antibacterial activities of Nigella sativa on mastaitis in dairy crossbred cows. Int J Adv Technical Res. 2013;3:263-272

22. Bakathir, H. A., \& Abbas, N. A. (2011). Detection of the antibacterial effect of nigella sativa ground seed swith water. African Journal of Traditional, Complementary and Alternative Medicines, 8(2).

23. Hanafy, M. S. M., \&Hatem, M. E. (1991). Studies on the antimicrobial activity of Nigella sativa seed (black cumin). Journal of Ethnopharmacology, 34(2-3), 275-278.

24. Hosseinzadeh H, FazlyBazzaz BS, MotevalyHaghi M. Antibacterial activity of total extracts and essential oil of Nigella sativa L. seeds in mice. Pharmacol online. 2007;2:429-435.

25. Zaidi, S. F. H., Yamada, K., Kadowaki, M., Usmanghani, K., \& Sugiyama, T. (2009). Bactericidal activity of medicinal plants, employed for the treatment of gastrointestinal ailments, against Helicobacter pylori. Journal of Ethnopharmacology, 121(2), 286-291.

26. Salman MT, Khan RA, Shukla I (2008). Antimicrobial activity of Black Cumin seeds (Nigella sativa) against multi-Drug resistant strains of Coagulase negative Staphylococci. Hippocratic J. Unani Med., 3: 107-112.

27. Morsi NM (2000). Antimicrobial effect of crude extracts of Nigella sativa on multiple antibiotic resistant bacteria. ActaMicrobiol. Polonica,49: 63-74.

28. El-Kamali HH, Ahmed AH, Mohammed AS, Yahia AMM, El-Tayeb IH and Ali AA (1998). Antibacterial properties of essential oils from Nigella sativa, Cymbopogoncitratus leaves and Pulicariaundulata aerial parts. Fitotherapia, 69:77-78.

29. Al-Jabre S, Al-Akloby OM, Al-Qurashi AR, Akhtar N, Al-Dossary A and Randhawa MA (2003). Thymoquinone, an active principle of Nigella sativa, inhibited Aspergillusniger. Pak. J. Med. Res., 42:102-104.

30. Ara N, Choudhury SAR and Amin A (2005). In vitro antimicrobial of the volatile oil of Nigella sativa Linn seeds. Teacher Aassos. J., 18:109-112.

31. Sitara U, Niazi I, Naseem J and Sultana N (2008). Antifungal effect of essential oils on in vitro growth of pathogenic fungi. Pak. J. Bot., 40: 409-414.

32. Halawani E (2009). Antibacterial activity of thymoquinone and thymohydroquinone of Nigella sativa L. and their interaction with some antibiotics. Advances Biol. Res., 3: 148-152

33. Mohammed MJ, Mahmood MT and Yaseen JM (2009). Biological effect of saponins Isolated from Nigella sativa (seeds) on growth of some bacteria. Tikrit J. Pure Sci., 14: 30-33.

34. Ismaeil AS (2011). Effect of black seed alkaloids against some pathogenic bacteria. Raf. J. Sci., 22: 9-16. 
35. Abo-Zeid, K., and Shohayeb, M. Evaluation of the biocidal activity of alkaloids, saponins and volatile oil extracted from Nigella sativa seeds against miracidia and cercariae of Schistosomamansoni. Int J Pharm Sci Invent, $4: 47-54$

36. Taskin MK, Caliskan OA, Anil H, Abou-Gazar H, Khan IA and Bedir E (2005). Triterpenesaponins from Nigella sativa L. Turk. J. Chem., 29: 561-569.

37. Dadawal AI, Chauhan HC, Chandel BS, Ranaware P, PatelKhushboo SS, Rathod SPH, Shah NM and Kher HN (2010). Assessment of Echerichia coli isolates for in vitro biofilm production. Vet. World, 3: 364-366.

38. Rashid HM and Kornberg A (2000). Inorganic polyphosphate is needed for swimming, swarming and twitching motilities of Pseudomonas aeruginosa. Proc. Natl. Acad. Sci. USA, 79: 4885-4890.

39. Hitchcock, PJ and Brown, TM (1983). Morphological heterogeneity among salmonella lipopolysaccharide chemotypes in silver-stained polyacrylamide gels. J. Bacteriol., 154: 269-277.

40. Tsai C and Frasch CE (1982). A sensitive silver stain for detecting lipopolysaccharides in polyacrylamide gels. Anal. Biochem., 119: 115-11.

41. Laemmli UK (1970). Cleavage of structural proteins during the assembly of the head of the bacteriophage T4. Nature, 227: 680-685.58- Korhonen TK, Lounatmaa K, Ramta H and Kuusi N (1980).Characterization oftype 1 pilli of Salmonella Typhimurium LT2. J. Bacteriol., 144: 800-805.

42. .Wray, W., Boulikas, T., Wray, V. P., \& Hancock, R. (1981). Silver staining of proteins in polyacrylamide gels. Analytical biochemistry, 118(1), 197-203.

43. Korhonen TK, Lounatmaa K, Ramta H and Kuusi N (1980).Characterization oftype 1 pilli of Salmonella Typhimurium LT2. J. Bacteriol., 144: 800-805.

44. Kokare, C.R.; Chakraborty, S.; Khopade, A.N.; Mahadik, K.R. Biofilm: Importance and applications. Indian J. Biotechnol. 2009, 8, 159-168.

45. Bjarnsholt T. (2013)The role of bacterial biofilms in chronic infections. APMIS Suppl.(136):1-51. doi: 10.1111/apm.12099.

46. 10. Koo, H.; Duarte, S.; Murata, R.M.; Scott-Anne, K.; Gregoire, S.; Watson, G.E.; Singh, A.P.; Vorsa, N. Influence of cranberry proanthocyanidins on formation of biofilms by Streptococcus mutans on saliva-coated apatitic surface and on dental caries development in vivo. Caries Res. 2010, 44, 116-126.

47. 11. Monte, J., Abreu, A. C., Borges, A., Simões, L. C., \&Simões, M. (2014). Antimicrobial activity of selected phytochemicals against Escherichia coli and Staphylococcus aureus and their biofilms. Pathogens, 3(2), 473-498.

48. 12. Packiavathy IASV, Agilandeswari P, Musthafa KS, KaruthaPandian S, Veera Ravi A. Antibiofilm and quorum sensing inhibitory potential of Cuminumcyminum and its secondary metabolite methyl eugenol against Gram negative bacterial pathogens. Food Research International. 2012;45(1):85-92.

49. 13. Niu C, Afre S, Gilbert ES. Subinhibitory concentrations of cinnamaldehyde interfere with quorum sensing. Letters in Applied Microbiology. 2006;43(5):489-494.

50. Chaieb K, Kouidhi B, Jrah H, Mahdouani K and Bakhrouf A (2011). Antibacterial activity of Thymoquinone, an active principle of Nigella sativa and its potency to prevent bacterial biofilm formation. BMC Complementary and Alternative Med., 11:29-34.

51. Borges, A., Abreu, A. C., Malheiro, J., Saavedra, M. J., \&Simões, M. (2013). Biofilm prevention and control by dietary phytochemicals. Microbial pathogens and strategies for combating them: science, technology and education. Formatex, 2, 32-41.

52. O'May C and Tufenkji N (2011). The swarming motility of Pseudomonas aeruginosa is blocked by cranberry proanthocyanidins and other tannin-containing materials. Appl. Environ. Microbiol., 77:3061-3067.

53. Dusane, D. H., Hosseinidoust, Z., Asadishad, B., \&Tufenkji, N. (2014). Alkaloids modulate motility, biofilm formation and antibiotic susceptibility of uropathogenic Escherichia coli. PloS one, 9(11), e112093.

54. O'May, C., Ciobanu, A., Lam, H., \&Tufenkji, N. (2012). Tannin derived materials can block swarming motility and enhance biofilm formation in Pseudomonas aeruginosa. Biofouling, 28(10), 1063-1076.

55. Borges, A., Abreu, A. C., Malheiro, J., Saavedra, M. J., \&Simões, M. (2013). Biofilm prevention and control by dietary phytochemicals. Microbial pathogens and strategies for combating them: science, technology and education. Formatex, 2, 32-41.

56. Amaral, L, Schwarz U, and Lorian V (1986). Penicillin-binding proteins of filaments of Escherichia coli induced by low concentrations of nalidixic acid, oxalinic acid, novobiocin, nitrofurantoin. Drugs. Exp. Clin. Res. 12:653656.

57. Hamilton-Miller JMT, Shah S (1999). Disorganisation of cell division of methicillin-resistant Staphylococcus aureus by a component of tea (Camellia sinensis): a study by electron microscopy. FEMS Microbiol. Lett., 176:463-469. 
58. Stapleton PD, Shah S, Taylor PW (2005). Altered cell surface properties and decreased autolytic activity in methicillin-resistant Staphylococcus aureus by epicatechingallate; International Union of Microbiological Societies, San Francisco, USA.

59. Darah I, Lim C L, NurulAili Z, Nor Afifah S and ShaidaFariza S (2011,): Effects of methanolic extract of a soft sponge, Haliclona sp. on bacterial cells: structural degeneration study. PharmacieGlobale (IJCP) 7:1-6

60. Sherman P, Cockerill III F, Soni R, and Brunton J (1991). Outer membranes are competitive inhibitors of Escherichia coli 0157:H7 adherence to epithelial cells. Infect. Immun. 59:890-899.

61. Bernardini ML, Sanna MG, Fontaine A, and Sansonetti PJ (1993). OmpC is involved in invasion of epithelial cells by Shigellaflexneri. Infect. Immun. 61:3625-3635.

62. Krachler AM, Ham H, and Orth K (2011). Outer membrane adhesion factor multivalent adhesion molecule 7 initiates host cell binding during infection by Gram-negative pathogens. Proc. Natl. Acad. Sci. USA, 108: 11614-11619.

63. Goh EB, Yim G, Tsui W, Mcclure J, Surette MG (2002). Transcriptional modulation of bacterial gene expression by sub-inhibitory concentrations of antibiotics. Proc. Natl. Acad. Sci. USA, 99:1705-1730

64. Santiago, C., Lim, K. H., Loh, H. S., \& Ting, K. N. (2015). Prevention of cell-surface attachment and reduction of penicillin-binding protein 2a (PBP2a) level in methicillin-resistant Staphylococcus aureus biofilms by Acalyphawilkesiana. BMC complementary and alternative medicine, 15(1), 1.

65. Wong, F. C., Yong, A. L., Sim, K. M., Ong, H. C., \& Chai, T. T. (2014). Proteomic Analysis of Bacterial Expression Profiles Following Exposure to Organic Solvent Flower Extract of Melastomacandidu m D Don (Melastomataceae). Tropical Journal of Pharmaceutical Research, 13(7), 1085-1092.

66. Molinaro, A., Newman, M.A., Lanzetta, R. and Parrilli, M. (2009). The structures of lipopolysaccharides from plant-associated gram-negative bacteria. Eur. J. Org. Chem., 34, 5887-5896 .

67. Pier, GB (2007).Pseudomonas aeruginosa lipopolysaccharide: a major virulence factor, initiator of inflammation and target for effective immunity. Int. J. Med. Microbiol, 297: 277-295.

68. Freudenberg MA, Merlin T, Gumenscheimer M, Kalis C, Landmann R, Galanos C (2001). Role of lipopolysaccharide susceptibility in the innate immune response to Salmonella Typhimurium infection: LPS, a primary target for recognition of Gram-negative bacteria. Microbes Infect., 3:1213-1222.

69. Meredith, T.C. Aggarwal, P., Mamat, U., Lindner, B., and Woodard, R.W. (2006). Redefining the requisite lipopolysaccharide structure in Escherichia coli. ACS Chem. Biol., 1, 33-42

70. Laird MW, Kloser AW, Misra R. Assembly of LamB and OmpF in deep rough lipopolysaccharide mutants of Escherichia coli K-12. J Bacteriol 1994; 178: 2259-2264.

71. Murray GL, Attridge SR, Morona R. 2003. Regulation of Salmonella typhimurium lipopolysaccharide O antigen chain length is required for virulence; identification of FepE as a second Wzz. Mol. Microbiol. 47:1395-1406. 